\title{
MILL'S FOURTH FUNDAMENTAL PROPOSITION ON CAPITAL: A PARADOX EXPLAINED
}

\author{
BY
}

STEVEN KATES

\begin{abstract}
John Stuart Mill's Fourth Fundamental Proposition Respecting Capital, first stated in 1848, had become an enigma well before the nineteenth century had come to an end. Never challenged in Mill's own lifetime and described in 1876 as "the best test of a sound economist," it has become a statement that not only fails to find others in agreement, but fails even to find an internally consistent interpretation that would make clear why Mill found it of such fundamental importance. Yet the fourth proposition should be easily understood as a continuation of the general glut debate. Economists led by Malthus had argued that demand deficiency was the cause of recession and a body of unproductive consumers was needed to raise the level of demand if everyone who wished to work was to find employment. Mill's answer was that to buy goods and services would not increase employment, or, in Mill's own words, "demand for commodities is not demand for labour."
\end{abstract}

\section{INTRODUCTION}

John Stuart Mill's fourth proposition respecting capital, that "demand for commodities is not demand for labor" (Mill 1921, p. 79), has in many respects the same mystery about it that Fermat's Last Theorem had in mathematics. ${ }^{1}$ The proposition is found in

\footnotetext{
Economics, Finance and Marketing, RMIT University, Melbourne, Australia. I am more than normally appreciative of the extensive comments provided by two anonymous referees, who have made this paper much better than it originally was. I am also extraordinarily grateful to the editor for his assistance and advice. 1"Fermat's Last Theorem states that no three positive integers $a$, b, and c can satisfy the equation $a^{n}+b^{n}=c^{n}$ for any integer value of $\mathrm{n}$ greater than two. This theorem was first conjectured by Pierre de Fermat in 1637, famously in the margin of a copy of Arithmetica where he claimed he had a proof that was too large to fit in the margin. No successful proof was published until 1995 despite the efforts of countless mathematicians during the 358 intervening years" (Wikipedia http://en.wikipedia.org/wiki/Fermat's_Last_Theorem (accessed November 11, 2014).
} 
a text of the highest reputation, Mill's Principles of Political Economy-arguably the nineteenth century's most influential text. Yet, it can no longer be explained in a way that makes clear why Mill considered it so fundamentally important.

In 1975, James Thompson, in the last major review of what was by then an almost hundred-year-old controversy, subtitled his article "a paradox revisited," with the word paradox lifted from Mill's own discussion (Mill 1921, p. 80). Indeed, Thompson goes farther, describing the proposition as "one of the discipline's most durable riddles" (Thompson 1975, p. 176), and, in summing up in the last paragraph of his article, he states of this proposition that "it remains an intriguing subject for discussion even today" (p. 192). ${ }^{2}$ Clearly, Thompson found no convincing explanation of what Mill had in mind or why Mill had found it of such importance, which is why, for him and for others, this proposition has remained a riddle and a paradox.

Thompson's inability to reach a firm conclusion is shown from the start in his opening sentence: "'Demand for commodities is not demand for labour' — so goes one of economics' strangest theorems" (Thompson 1975, p. 174). Strange, presumably, because he could find no explanation for what Mill had written that fully satisfied him. In this, he is joined by virtually the entire economics profession.

Alfred Marshall is an interesting example. Having already discussed his fundamental rejection of the proposition in the first edition of his Principles, where he wrote that the wording "expresses [Mill's] meaning badly," he later added, to emphasize his disagreement, a marginal note for the relevant paragraph, which read, "Demand for commodities is generally demand for labour" (Marshall 1947, p. 828; my italics), stressing the opposite of what Mill had written. For Marshall, as for others since Mill's time, an increase in the demand for commodities is an increase in the derived demand for labor. It never occurs to Marshall that he may not have understood Mill's actual intent.

Several questions therefore arise. What did Mill mean? Was Mill's proposition sensible and coherent? Did it require some special assumption that we have since discarded, such as the wages fund? Why could Leslie Stephen in 1876 describe Mill's fourth proposition as "the doctrine-so rarely understood, that its complete apprehension is, perhaps, the best test of a sound economist" (Stephen 1876, p. 297), emphasizing both how infrequently economists even in his own time were capable of making complete sense of Mill's proposition, while also specifically stating how crucial he believed understanding Mill's proposition is if one is actually to understand how an economy works?

Going further, the question that presents itself is, what had happened to the way economists thought about economic issues, so that less than fifteen years after Stephen had written his words, Marshall could no longer accept Mill's meaning without major qualification? Is there, therefore, some discontinuity between Marshall's way of conceiving economic issues through to the present day and the way they had been conceived by his classical predecessors? And, indeed, this paper will argue that there has been just such a discontinuity. It will be argued that the basis for understanding Mill depends on a proper understanding of Say's Law as it was understood by Mill and his

\footnotetext{
${ }^{2}$ In point of fact, I have twice discussed, and attempted to explain, Mill's fourth proposition on capital. See Kates (1998, pp. 68-73; 2014, pp. 105-111). The second of these is probably the first time in well over a century that Mill's fourth proposition-indeed, all four propositions - have been included as an integral component of an introductory text on economics.
} 
classical contemporaries, an understanding that was weakened during the Marginal Revolution and then almost entirely lost with the publication of John Maynard Keynes's General Theory two generations after that.

\section{OUTLINE OF THE ARGUMENT PRESENTED}

For someone coming upon this issue without having engaged with the literature, why Thompson referred to Mill's fourth proposition as a "paradox" will itself seem a paradox, since the explanation provided in this paper will appear natural and, I hope, straightforward. But it is a fact that there has been an extensive literature on this issue that has never been able to provide a satisfying and coherent explanation for what Mill was trying to argue. Since Leslie Stephen's 1876 offhand comment, not only has no economist defended Mill's fourth proposition as sensible, coherent, and internally consistent, no one has even been able to explain why it had made sense to Mill or why he found it so important. Therefore, to follow the argument, it is first necessary to explain in advance how each of the sections of the present paper contributes to a full understanding of what Mill had in mind.

First, there is the need to understand the meaning of Say's Law to Mill and his contemporaries. ${ }^{3}$ As a short-form definition, "demand for commodities is not demand for labour" may itself be as accurate as anything that might be found today. Keynes, in rejecting this principle, which he referred to as "Say's Law," argued that an increase in aggregate demand would lead to an increase in the demand for labor. It is this "Keynesian" view that Mill had been emphatically rejecting.

Second, there is a discussion of Thompson's 1975 article. What is significant is that Thompson can perfectly well see that Mill is attempting to defend Say's Law but is unable to follow Mill's logic, since he is trapped in the Keynesian version of "supply creates its own demand" and especially the assumption of full employment, the interpretation universally accepted following the publication of The General Theory.

Third, there is a discussion of the general glut debate, which commenced immediately after the publication of Malthus's Principles in 1820. As will be argued, Mill's fourth proposition is a summary of the conclusion reached by the mainstream of the profession in the wake of that debate.

Fourth, there is a discussion of all four of Mill's propositions. Seen in context, the point Mill is trying to make in the fourth proposition follows directly from the first three.

Fifth, the question is then raised as to why Mill's proposition, which was universally accepted in his own time, almost immediately disappeared from within economic discourse and not only was no longer accepted by the economics community, but could not even be understood. It is argued that the Marginal Revolution, which shifted the focus from the supply side to the demand side and from "macro" to "micro," caused the meaning of Mill's fourth proposition to be lost.

\footnotetext{
3"Say's Law" is used as the term for the principle that Mill was attempting to defend, which states that recessions are not caused by demand deficiency and could not be cured by an increase in unproductive spending. "The Law of Markets," the principle developed by Say, argues that demand is constituted by supply, one of the underlying reasons for accepting Say's Law but not the central issue in the general glut debate. See Kates (1998, pp. 75-76) for a discussion of the associated concepts underlying this classical principle.
} 
Sixth, there is an examination of three of economic theory's most eminent economists-Alfred Marshall, Allyn Young, and Friedrich Hayek — who had attempted to make sense of Mill's fourth proposition in the period prior to the Keynesian Revolution. Their inability to follow Mill's point is quite instructive of the difficulty involved in making sense of the economic views of earlier generations. There is also a discussion of Sam Hollander's more recent examination of this proposition centered on, but not entirely relying on, his two-volume study of the economics of John Stuart Mill (1986).

Seventh, there is a discussion of the effect of the Keynesian Revolution on our collective understanding of Mill's fourth proposition. Keynes, in attempting to refute Say's Law, was specifically attempting to show that the demand for commodities is demand for labor. As a consequence of the Keynesian Revolution, it will be argued, the reasoning behind the point Mill had been trying to make became even more difficult to comprehend.

\section{THE CLASSICAL MEANING OF SAY'S LAW}

In understanding the point John Stuart Mill was trying to make, it is crucial to understand what he understood by "Say's Law," a term Mill and his contemporaries did not use, since it was a phrase not coined until the twentieth century. The barrier to our understanding of Mill's fourth proposition exists because the meaning to Mill of Say's Law and its meaning today are vastly different. To understand the meaning to Mill's contemporaries, it is necessary to see how this concept developed into one of the basic components of classical theory, which originated during an obscure debate between William Spence and James Mill, J. S. Mill's father, that took place during the Napoleonic Wars. ${ }^{4}$ The French had blockaded European ports and reduced the level of England's export trade. Spence wrote his Britain Independent of Commerce (1807) to argue that there was no need for concern about this loss of trade. In his view, since an economy is driven by spending rather than saving, the missing demand could be made up by encouraging expenditure by the landed classes. In reply, in 1808 James Mill wrote his Commerce Defended, one chapter of which was devoted to refuting Spence's argument in relation to demand.

The question he was seeking to answer was, what would make demand effective? ${ }^{5}$ Certainly you could increase the level of spending, but what would be required to cause such an increase in expenditure to lead to an increase in economic activity and employment? In framing his answer, he referred to Say's Treatise, which had been published only a few years before in 1803, and took from it that demand is constituted by supply. For money demand to be effective, the money spent had to have been earned by producing something else.

These issues remained quiescent, although not entirely dormant, until the publication of Thomas Robert Malthus's Principles of Political Economy in $1820 .{ }^{6}$ There Malthus

\footnotetext{
${ }^{4}$ This section is adopted from chapters 2 and 3 of Kates (1998).

${ }^{5}$ This is somewhat different from Keynes's question, which was: what actions should be taken to increase the level of employment during recession? The shift in the relevant term from "effective demand" to "aggregate demand" is a tacit recognition of the subtle shift in the underlying question being posed.

${ }^{6}$ See Thweatt (1979) for a discussion of the subterranean, but ongoing, debate that continued through until the publication of Malthus's Principles.
} 
argued that the recessions that had followed the Napoleonic Wars had been caused by a deficiency of demand and that the solution would be an increase in unproductive expenditure, again by the landed classes. But this time, there was a free-for-all in which every major economist of the time became engaged. This controversy has come down to us as "the general glut debate," and the conclusion reached remained the bedrock position of almost the whole of the mainstream until the publication of The General Theory in 1936. And the conclusion that was maintained throughout this period was this: that demand deficiency was not a legitimate explanation for recessions and that unproductive expenditure was not a cure for recessions when they arose.

While the origin of this principle is now generally attributed to Say, since it is almost universally referred to as Say's Law, it may not actually be his own. It was James Mill who, in 1808, had adopted the principle he had found in Say and applied it to the policy question of whether an economy could be driven from the demand side. When the same issue arose again in 1820, Say (in his Letters to Mr. Malthus published in French in 1820 and in English in 1821), James Mill (in his Elements of Political Economy first edition also published in 1821), along with virtually every major economist of the time (Sowell 1972, p. 115), took up that same debate to reach the collective conclusion they did. But at no stage during the nineteenth century was this principle referred to as "Say's" Law.

It is therefore important, when reading the term "Say's Law," to recognize its shifting meanings, and in particular the meaning that this at-the-time unnamed principle originally held as a consequence of the general glut debate. It is this meaning that needs to be contrasted with the meaning it took on following the Keynesian Revolution. Keynes defined what he specifically referred to as Say's Law as "supply creates its own demand," by which he meant that everything produced would be bought. From this, Keynes argued that economic theory right up to his own day, following in the wake of what he described as "Ricardian economics" (Keynes 1973, p. 3n), always tacitly assumed an economy was at full employment and that therefore there was no explanation for involuntary unemployment within the classical tradition. It is this interpretation that has become embedded within modern economics, even though it does not express the core conclusion that had been almost universally accepted by the end of the general glut debate and for almost a hundred years thereafter. Ricardo, replying in a letter to Malthus in 1820, that "men err in their productions; there is no deficiency of demand" (Ricardo 1951-1973, VIII, p. 277), provides the best short statement of the classical position. Recessions do occur that are caused by errors in production decisions, not because there is too little demand for what had been produced.

\footnotetext{
${ }^{7}$ The term "Say's Law" was coined in the twentieth century by Fred Taylor (Kates 1998, pp. 148-149) precisely because, as he wrote, this principle did not already have a name. Taylor's first use of it in print did not occur until 1909 in an obscure article on the teaching of economics. It became part of the general discourse among economists only in the 1920s following the publication of Taylor's textbook on introductory economic theory. There had been seven student editions of Taylor's text used at the University of Michigan since 1911, but the first commercially published version did not appear until 1921, and was designated as the eighth edition. Because of its origins in the US, the term "Say's Law" was used almost exclusively on the American side of the Atlantic until it appeared in The General Theory.
} 


\section{THOMPSON ON SAY'S LAW}

It is in this context that Thompson's discussion must be framed. What is quite noteworthy is that Thompson (1975, p. 178) not only recognizes that Mill's fourth proposition is the logical extension of the first three, but also that it has been derived from what he calls "Say's Law." The problem, though, is that he does not understand what Say's Law meant to Mill and others within the classical school. He can thus state the following but still not understand the implications of what he wrote: "If considered strictly in terms of the theoretical framework employed by Mill, the fourth fundamental proposition hardly deserves the appellation 'paradox.' On the contrary, it follows quite logically from his assumptions . . . besides all that is implied in a broad interpretation of the wages-fund and Say's Law" (1975, p. 178). Thompson then adds for emphasis: "The theorem follows almost by necessity when the wages-fund doctrine is combined with Say's Law. Hence it is more properly regarded as a natural by-product of the classical system than as Mill's exclusive property" (p. 178).

In a sense, one could argue, he sees what Mill is trying to argue and has provided an explanation. Yet, what is clear is that, having made these points, Thompson is left unsatisfied. He sees what the text has said but cannot work out why Mill goes to such lengths to explain and defend his fourth proposition. Neither can he see why anyone would find it such an important statement of economic principle. The problem for Thompson is that he is trapped by the common understanding of Say's Law at the time he wrote. Whether he followed Keynes in accepting that Say's Law meant full employment is always assumed, or had instead followed Gary Becker and William Baumol's (1952) slightly weaker interpretation in arguing that the meaning of Say's Law was embodied in what they called "Say's Equality" (so that even if recessions occurred, they would be shallow and brief), the end result is that Thompson assumes Mill is discussing an economy in which unemployment is not a serious issue. Given this assumption, an increase in the demand for commodities is therefore not an increase in the demand for labor because everyone is already employed. Thompson's interpretation of Mill vis-à-vis the then-current understanding of Say's Law is explained towards the end of his paper, even though, as he notes, Simon Newcomb, writing in 1886, had clearly recognized the existence of large-scale unemployment: ${ }^{8}$

Incidentally, Newcomb's insistence that the existence of unemployment is implied in Mill's principal illustration is given some support by the fact that Mill subsequently made the theorem the basis of an attack on the English poor law. This would seem to imply that he did not restrict its application to a situation of full employment.

\footnotetext{
${ }^{8}$ Newcomb's discussion of Mill's fourth proposition was published a decade after Stephen's statement and more than a decade after Mill's death and the commencement of the Marginal Revolution. Newcomb nevertheless sides to a much greater extent with Mill than with Marshall and recognizes that unemployment is common (Newcomb 1886, pp. 438-439). In his seven-page appendix on Mill's fourth proposition, which he titles "The Relation of Demand for Commodities to Demand for Labour" (1886, pp. 434-440), he begins his analysis with the observation: "Taken literally it is undoubtedly correct. . . Buying things does not make them" (pp. 434-435). It might also be noted that Newcomb, like others after him, reworks Mill's original statement, writing " $a$ demand for commodities is not $a$ demand for labour" (p. 434; italics added), which he even puts in quotation marks. Inclusion of the indefinite article makes a material difference to the meaning of the phrase, embedding it in a more microeconomic frame.
} 
His conception of Say's Law, of course, did not rule out the existence of temporary unemployment. Yet Newcomb's suggestion of a chronically unemployed class goes too far and must be adjudged incompatible with Mill's theoretical assumption. (Thompson 1975, p. 188)

Given his acceptance of the full-employment version of Say's Law, Thompson is unable to see the point Mill is trying to make. But, as will be argued below, Mill meant his fourth proposition to apply to situations where large-scale unemployment exists. His point was that even with high unemployment, an increase in demand would not lead to an increase in the number of jobs. Thompson, by beginning with the assumption that Mill had, for all practical purposes, assumed a fully employed economy, or one in which full employment would swiftly return if unemployment occurred, cannot in the end make satisfying sense of the fourth proposition. Neither could he find any satisfaction within any of the other interpretations whose efforts he discusses. None, in his view, were able to decipher Mill or provide a coherent and satisfying explanation of what Mill had meant.

This paper will, however, attempt to explain Mill's meaning in a way that not only demonstrates the internal coherence of his statement, but will also argue that the fourth proposition and the first three together provide a logical and cohesive understanding of the operation of an exchange economy, based as they are on an understanding of the classical meaning of Say's Law. Moreover, the demonstration that demand for commodities is not demand for labor requires no retreat into classical presuppositions such as the wages fund to explain why this may be the case, or any reading into the text of some principle left unstated on the pages of Mill's Principles.

\section{THE GENERAL GLUT DEBATE}

What is important is to understand that the four propositions are a summary of the mainstream classical position in the aftermath of the general glut debate. Unless these four propositions are seen as a reply to the controversy touched off by Malthus in 1820 , the point Mill is attempting to make will be lost. Malthus had argued that oversaving and demand deficiency were the cause of then-existing recessionary conditions and high levels of unemployment. The four propositions taken together are a direct response to those who had argued that there was a limit to the level of economic activity set on the demand side of the economy. It is in his discussion of the first proposition that the central point intended by Mill is found. There, he wrote, "Every increase of capital gives, or is capable of giving, additional employment to industry; and this without assignable limit" (Mill 1921, p. 66). Then, in a reference whose significance would have been completely clear to his contemporaries, Mill wrote:

Authors of the highest name and of great merit have contended, that if consumers were to save and convert into capital more than a limited portion of their income, and were not to devote to unproductive consumption an amount of means bearing a certain ratio to the capital of the country, the extra accumulation would be merely so much waste, since there would be no market for the commodities which the capital so created would produce. I conceive this to be one of the many errors arising in political economy, from the practice of not beginning with the examination of simple cases, but rushing at once into the complexity of concrete phenomena. (1921, p. 67) 
And, if there were still any lingering doubt about who and what he meant, there is a footnote that follows the phrase "authors of the highest name and of great merit," which reads: "For example, Mr. Malthus, Dr. Chalmers, M. de Sismondi" (1921, p. 67n). All three-Malthus, Chalmers, and Sismondi-had argued that overproduction and demand deficiency were the causes of recession. They were, in their own time, the three most prominent protagonists arguing that a general glut was a genuine possibility. That they are identified in this footnote emphasizes how the fourth proposition is merely the summation of the argument against those who had argued in favor of the possibility of a general glut and had consequently argued in favor of encouraging additional unproductive spending to overcome the possibility of recession due to too little demand. This was clearly stated by Malthus in his Principles, whose publication had touched off the general glut debate:

The third main cause which tends to keep up and increase the value of produce by favouring its distribution is the employment of unproductive labour, or the maintenance of an adequate proportion of unproductive consumers. . . It is absolutely necessary that a country with great powers of production should possess a body of unproductive consumers. (Malthus 1986, II, p. 462)

An unproductive consumer is someone who buys without contributing to the supply of value-adding output. Their communal benefit, according to Malthus, is to add to the demand for commodities without contributing more to those already glutted markets. Increasing demand without simultaneously increasing supply will lead to an increase in employment. That is the point of having "unproductive" consumers. He wants only people who will buy, not produce (see Kates 1998, pp. 50-51). In writing the fourth proposition, Mill is merely stating that increases in the demand for commodities is not, as Malthus and others had seemed to believe, an increase in the demand for labor.

Importantly, in his statement, Mill not only denies that recessions are caused by deficient demand, but also makes the further point that artificially attempting to increase demand, output, and employment by the mere purchase of commodities will be unsuccessful, even counterproductive. He is adamant that buying final goods and services without adding to the productiveness of the economy cannot lead to an increase in the demand for labor. Irrespective of whether there are unemployed resources, Mill is arguing that increasing the level of unproductive expenditure cannot increase the number of persons employed and, if attempted, will not succeed.

That this is what Mill had in mind is further demonstrated in a footnote reference found in Book III, Chapter XIV, "Of Excess of Supply." This is the chapter in which Mill specifically denies the possibility of a general glut, providing the classical statement on Say's Law. At the start of the chapter, Mill writes:

Because this phenomenon of over-supply, and consequent inconvenience or loss to the producer or dealer, may exist in the case of any one commodity whatever, many persons, including some distinguished political economists, have thought that it may exist with regard to all commodities; that there may be a general over-production of wealth; a supply of commodities in the aggregate, surpassing the demand; and a consequent depressed condition of all classes of producers. Against this doctrine, of which Mr. Malthus and Dr. Chalmers in this country, and M. de Sismondi on the Continent, were the chief apostles, I have already contended in the First Book;* [sic] 
but it was not possible, in that stage of our inquiry, to enter into a complete examination of an error (as I conceive) essentially grounded on a misunderstanding of the phenomena of Value and Price. (Mill 1921, pp. 556-557)

The asterisk “*” leads to a footnote, which reads, "Supra, pp.66-8” (Mill 1921, p. 557n). This refers the reader back to Mill's chapter on his fundamental proposition on capital and specifically to the discussion of his first proposition. And, at the start of this discussion, we again find: "Every increase of capital gives, or is capable of giving, additional employment to industry; and this without assignable limit" (p. 66).

The conclusion at the end of the section (p. 68) emphasizes once more that it is not demand deficiency that is the cause of recessions, but an absence of productive power.

Thus the limit of wealth is never deficiency of consumers, but of producers and productive power. Every addition to capital gives to labour either additional employment, or additional remuneration; enriches either the country, or the labouring class. If it finds additional hands to set to work, it increases the aggregate produce: if only the same hands, it gives them a larger share of it; and perhaps even in this case, by stimulating them to greater exertion, augments the produce itself.

Mill has thus referred to the arguments on the four propositions on capital to explain why neither too much saving nor too little demand can lead to unemployment, whichmost importantly in the context of the fourth proposition-cannot be cured by an increase in unproductive spending. Mill's contemporaries, who had grown up in the midst of the general glut debate, would have had no difficulty in understanding there is no assumption that the economy is fully employed. Mill can be arguing that additional capital can lead to more employment "if it finds additional hands to set to work" only if he accepts that there can be unemployed persons who could be set to work if more capital were somehow made available.

\section{MILL'S FOUR PROPOSITIONS}

It is therefore useful to examine all four of Mill's propositions on capital in order to understand his fourth within the context of the other three. The following discussion explains Mill's meaning in relation to each of the four propositions.

\section{Mill's First Proposition}

Mill's first proposition states that "industry is limited by capital." It states that the total output of an economy is held within limits set by the amount of capital available. There is only so much that can be produced, given the available resource base, and this resource base can either be applied to the production of consumption goods or used to add to the economy's capital base. Capital, it should be further understood, was any and every available resource that was used by its owner to earn an income. Labor cannot be employed without capital: "There will not and cannot be more of that labour than the portion so allotted (which is the capital of the country) can feed, and provide with the materials and instruments of production" (Mill 1921, p. 64; italics added). 
This is not wages fund. Mill means something more comprehensive than just the availability of food, shelter, and clothing for the working population, since, beyond merely feeding the population, Mill explicitly notes that it is also necessary to provide "materials and instruments of production." Also included are foundries, power looms, and every other produced form of input into the production process. That this is Mill's meaning for the term "capital" is clearly explained in the previous chapter (Book I, Chapter 4), simply titled "Of Capital," in which Mill describes the particular kinds of items that might be included as part of the capital of a manufacturer. There he explicitly lists buildings, machinery, raw material inputs, food and clothing, and finished goods ready for sale as forms of capital (Mill 1921, pp. 54-55). The productive efforts of an economy are limited by the supply of productive resources in all their different forms. The more capital there is, the more employment there can be. Leslie Stephen states on the page following his previously cited more famous quotation "that the capital employed constitutes the demand for labour” (1876, p. 298), a conclusion directly derived from Mill.

\section{Mill's Second Proposition}

Mill's second proposition states that "capital . . . is the result of saving" (Mill 1921, p. 68). In Mill's words, "To consume less than is produced, is saving; and that is the process by which capital is increased" (1921, p. 70). Saving is discussed in real terms. The source of resources with which to invest are made available only because some resources have been saved; that is, not used as current consumption.

\section{Mill's Third Proposition}

Mill's third proposition is that saving is not an abyss, a negative, an absence, but is instead an actual productive use of resources. Mill again: "Capital ... although saved, and the result of saving, it is nevertheless consumed" (1921, p. 70). Consumed here is not in its modern sense of forming part of final consumer demand, but means that the goods and services in question are being put to use in some kind of productive activity by being converted into capital. The word consumed and its various derivatives in the following passage should be read in the sense of "put to use." "The word saving does not imply that what is saved is not consumed, nor even that its consumption is deferred; but only that, if consumed immediately, it is not consumed by the person who saves it" (1921, p 70).

Savings are part of an economy's productive efforts. They are actual resources used to increase that economy's capital base. They are productive capital items plus the various goods and services bought by wage earners, all of which are funded out of national saving. ${ }^{10}$

\footnotetext{
${ }^{9}$ Consumed, to use Ricardo's more graphic example, as in consumed by a fire (Ricardo 1951-73, II, pp. 421-422). So far as any time period is concerned, even if labor and capital items remain in existence when the time period ends, the productive services they had offered have completely disappeared into the past, having been used in one way rather than some other.

${ }^{10} \mathrm{As}$ one of my students put it, are the wages of the person who made a camera paid by the person who bought the camera? Since obviously they are not, but have been paid through advances out of savings, failing to take into account the need to remunerate labor while productive activity takes place ignores an important aspect of the production process. An agricultural community, for example, lives on last year's crop while producing this year's, which they will live on while producing the crop for the year to follow.
} 


\section{Mill's Fourth Proposition}

Mill's fourth fundamental theorem respecting capital is, however, where the "paradox" is found. It is this proposition-quoted here in full and not just restricted to its second sentence - that has been the puzzle since the 1870s:

What supports and employs productive labour, is the capital expended in setting it to work, and not the demand of purchasers for the produce of the labour when completed.

Demand for commodities is not demand for labour. (1921, p. 79)

This is, to modern ears, virtually incomprehensible, all the more so since Keynesian theory has the opposite conception embedded as its own fundamental assumption. In a Keynesian world, demand for commodities most emphatically is demand for labor. Yet, as Thompson notes, "criticism of the theorem was uncommon during Mill's lifetime. One can only surmise that it met with the approval of most economists of that period" (Thompson 1975, p. 179). Since the only "notable exception" Thompson could find was George J. P. Scrope, and that was not until the 1870s, there is every reason to believe Mill's fourth proposition was indeed accepted virtually across the board amongst his contemporaries. Yet, given the effort Mill makes to explain this proposition, and the interesting concession he makes about the difficulty he has found in getting others to apply it in all instances where it ought to be applied, acquiescence did not necessarily imply full comprehension. From Mill's perspective, this was a proposition that was far from universally understood in the heat of argument: "It is, to common apprehension, a paradox; and even amongst political economists of reputation, I can hardly point to any, except Mr. Ricardo and M. Say, who have kept it constantly and steadily in view" (Mill 1921, p. 80).

In the continuation of this passage, Mill makes a statement that underscores the point he is trying to make: "Almost all others occasionally express themselves as if a person who buys commodities, the produce of labour, was an employer of labour, and created a demand for it as really, and in the same sense, as if he bought the labour directly, by the payment of wages" (1921, p. 80). And then he adds in exasperation a complaint about the shallowness of economists and economic theory if the belief that buying things is the same as actually hiring labor cannot be eradicated: "It is no wonder that political economy advances slowly, when such a question as this still remains open at its very threshold" (1921, p. 80).

It is this implicit assumption that to buy commodities is the same as to employ workers that Mill was attempting to deny. He was trying to demonstrate that to buy goods and services not only does not add to the demand for labor, such increases in the demand for commodities, if they reduce the supply of capital, can even cause the number of persons employed to fall.

\section{THE MARGINAL REVOLUTION AND THE DEMAND FOR COMMODITIES}

Why, then, did Marshall and his contemporaries, along with virtually all economists since the end of the nineteenth century, fail to understand Mill's fourth proposition? Something takes place between 1876, when Leslie Stephen can describe Mill's fourth 
proposition as the best test of a sound economist, and Marshall's virtual dismissal of Mill's statement a mere decade and a half later. What made the difference was the Marginal Revolution, the formalization of a theory that placed the determination of value on marginal utility. It thus took the focus of economic analysis from the supply side of the economy to the demand side, diminishing supply-side considerations to a very considerable extent. In an important sense, economic theory goes from being a macroeconomic inquiry into the nature and causes of the wealth of nations to become a microeconomic study of individual decision making and the logic of choice.

With the supply side of the economy shifted towards the background, the conceptual tools necessary to understand Mill withered. ${ }^{11}$ The very way in which economic issues were framed and understood radically altered in ways that made it almost impossible to understand the framework required if one were to believe that an increase in demand for commodities was not equivalent to an increase in demand for labor. Both Marshall and Friedrich Hayek, who stated support for Mill's proposition, in the end, could not see Mill's point.

Thompson also looks at the possibility that the change in the nature of economic theory had made it impossible to follow Mill's meaning. This possibility is discussed within the context of a Kuhnian paradigm shift. Thompson rejects this possibility:

\begin{abstract}
The inability of marginal utility theorists of the period to perceive any appreciable truth in Mill's fourth proposition could easily be interpreted as a typical example of incommensurability. It is necessary, of course, to explain the awkward fact that this reaction proved to be a temporary one. Within a decade or two, such writers as Marshall, Wicksell, and Newcomb were able to consider Mill's theorem with moderation and objectivity. This fact is not believed to present a serious barrier to the application of the incommensurability thesis, however. Incommensurability was pictured by Kuhn as primarily a phenomenon of the crisis period when a paradigm shift was in progress. With the passage of sufficient time, the work of translation could be accomplished, making a valid reinterpretation of an old proposition entirely possible. (Thompson 1975, p. 191)
\end{abstract}

This may be so as a general case, but, in this instance, Mill's fourth proposition appears to have become almost impossible to fathom because of the change in the way economists looked at economic issues.

\title{
VIII. INTERPRETATIONS OF MILL
}

A discussion of four economists who did not fully understand Mill's point is provided to indicate just how difficult it is for economists of one era to understand the economics of another when the underlying presuppositions have shifted. The examples are Alfred Marshall, Allyn Young, Friedrich Hayek, and Sam Hollander. While each of the first three tries to show agreement with Mill, in the end, they are unable to grasp in full the point Mill is trying to make. Hollander, whose main contributions on Mill were

\footnotetext{
${ }^{11}$ Hayek (1941) made a similar point and with specific reference to Mill's fourth proposition. He wrote "that in more modern times the doctrine has suffered a marked eclipse is mainly due to the fact that the modern subjective theory of value was erroneously thought to have provided an effective refutation" (Hayek 1941, p. 434).
} 
published in the 1980s and therefore well after the Keynesian Revolution, although providing a largely penetrating analysis of Mill's economic arguments, fails to make sense of Mill's fourth proposition and, thus, has little sympathy for the point Mill was trying to make.

\section{Alfred Marshall}

In an appendix on "The Doctrine of the Wages Fund" in his Principles, Marshall wrote that the "Demand for commodities is not demand for labour: and this again expresses his [Mill's] meaning badly" (Marshall 1947, p. 828). In trying to explain what he describes as Mill's badly expressed meaning, the most that Marshall is willing to concede is that "there is a sense in which this contains a little truth" (ibid., p. 828). But if one reads Marshall, it is clear he is floundering. Although he would like to present a robust and logical explanation for Mill's conclusion, in the end he finds he cannot. He specifically argues that Mill seems, in his view, to be saying something he could not possibly have been trying to say, that Mill "seems to imply that, to spend money on the direct hire of labour is more beneficial to the labourer than to spend it on buying commodities." Since that was indeed what Mill was trying to say, it is evident that Marshall can make neither heads nor tails of Mill's logic, which is why he wrote as a marginal note that "demand for commodities is generally demand for labour" (ibid., p. 828; my italics). This is so even though Marshall accepted the supply-side arguments of the classical economists and in another context had explicitly accepted the validity of Say's Law (on this, see Kates 1998, pp. 84-88).

\section{Allyn Young}

An interesting discussion of Mill's fourth proposition is found in Allyn Young's published lecture notes for the years 1927 to 1929. He follows Marshall in interpreting Mill in terms of the wages fund doctrine, but adds a different and more realistic dimension.

Mill really meant by his statement, 'demand for commodities is not demand for labour' that the demand for labour depended upon the employer who paid the labourer during production; and the demand for the product depended on the consumer. $\mathrm{He}$ thought in terms that were too inelastic, of a predetermined fund, and not of something fluid. The wages fund viewed as a flow is a much more flexible thing than the older economists thought it. (Sandilands 1990, pp. 75-76)

This is a useful and largely accurate interpretation of Mill, so far as it goes. Producers and consumers are the same set of individuals but at different moments in time. Consumers buy what has been produced, after it has been produced. When acting as producers, they are consuming the products of a previous period. Thus, the demand for commodities is not the demand for labor, since whatever is being consumed is the result of labor that was undertaken at an earlier period. It is only a forward-looking entrepreneurial decision to hire that puts someone to work, with the decision to employ based on an expectation of future sales. While this is a useful interpretation, ${ }^{12}$ it cannot

\footnotetext{
${ }^{12}$ It is discussed in Kates (2014, pp. 110-111).
} 
be the complete answer. Using this logic, one could argue that the demand for commodities in the present will encourage others to produce the same commodities in the future so that, in this sense, buying goods and services that have already been produced becomes the reason why producers will continue to produce to find consumers in the future. With Young's interpretation, we have a more sophisticated time-period-related relationship between buying and employing. It is not, however, what Mill had in mind, since his own examples are of decisions either to consume or to add to an economy's capital base. It is the existence of capital at the moment when production is taking place that allows employment in the examples Mill provides.

\section{Friedrich Hayek}

Hayek provides a comprehensive assessment of Mill's fourth proposition in his Pure Theory of Capital (2009, pp. 433-439). Like Alfred Marshall's, his discussion is found in an appendix to the main text, and, again like Marshall, Hayek sees Mill's fourth proposition being "closely connected with the wage fund theory" (2009, p. 433). $\mathrm{He}$, however, conceives the nature of what Mill had written in his own terms as a shift of relative prices between the stages of production, a conceptual apparatus totally foreign to Mill's approach. Moreover, in attempting to explain Mill's meaning, Hayek commences by reinterpreting what Mill had actually said:

Before we proceed further, however, it will be advisable to re-state Mill's proposition in a form which leaves no doubt about its exact meaning. In the first instance it is probably clear from that use to which the doctrine has been generally put that we are entitled, as we have already done, to substitute consumers' goods for 'commodities' and that the 'demand for commodities' will have to be described, not as a simple quantity, but as a demand schedule or curve describing the quantities of consumers' goods that will be bought at different prices. Secondly, the test of whether demand for consumers' goods 'is' demand for labour (or, we may say, demand for pure input) must clearly be whether a rise in the demand curve for consumers' goods raises the demand curve for pure input (and whether a lowering of the former lowers the latter), or whether a change in the demand for consumers' goods causes no change in the same direction or perhaps even a change in the opposite direction to the demand for pure input. (Hayek 1941, pp. 435-436)

Both of Hayek's "clarifications" move the train of logic well away from Mill. To equate commodities with consumer goods and to turn it into a schedule are interpretations not based on Mill's text. Commodities, to Mill, are goods consumed in the present without leaving behind a more productive economic environment. It is not just end-consumers who may do so but governments as well, and, in some instances, even businesses will do so. And then, secondly, Hayek transfers the meaning of the demand for labor into the "demand for pure input," by which Hayek means much more than just labor, but includes all forms of input into the production process. The crucial point Mill was trying to make on the relationship between the availability of capital and the level of employment disappears.

It is actually worse. There has been some debate over the years, to which Hayek himself has contributed, as to why he had not responded to the General Theory immediately after publication. The reason might, in fact, be that, so far as Keynes's main 
point was concerned, he and Keynes were in agreement. Mill had been trying to argue that an increase in the demand for goods and services would not lead to an increase in employment. Hayek, however, agreed with Keynes that in times of high unemployment, increased demand for commodities would lead to greater employment.

That under conditions of under-employment the general principle does not directly apply was of course well known to 'orthodox' economists, and to J. S. Mill in particular. In his exposition the statement that 'industry is limited by capital', on which, as we have seen, the proposition under discussion is based, is immediately followed by the further statement that it 'does not always come up to that limit'. And few competent economists can ever have doubted that, in positions of disequilibrium where unused reserves of resources of all kinds existed, the operation of this principle is temporarily suspended, although they may not always have said so. (Hayek 1941, p. 439)

In other words, when there are unused resources, the demand for commodities does constitute demand for labor. From this, the conclusion Hayek reaches is very different from Mill's: "More than ever it seems to me to be true that the complete apprehension of the doctrine that 'demand of commodities is not demand for labour' - and of its limitations - is 'the best test of an economist" (Hayek 1941, p. 439; my italics). A strange conclusion to reach, given that Mill had considered this one of his "fundamental" propositions on capital. It could not have been all that fundamental if it contained the kinds of "limitations" Hayek described.

\section{Sam Hollander}

Samuel Hollander has written exhaustively on Mill's economics, including a twovolume analysis devoted entirely to this subject. He has discussed Mill's fourth proposition extensively and on a number of occasions (Hollander 1985, pp. 371-376; 1987, pp. 183-184, pp. 209-213; 2000, ch. 7). While most of what Hollander writes is sensible and accurate, he misses the main point of why Mill had gone to so much trouble in emphasizing the fourth proposition in the way he did. Most importantly, Hollander does not attempt to explain why Mill had believed this proposition to be of such fundamental importance. More noteworthy is that in no part of this discussion does he invoke Say's Law. But the most important failing in his discussion is in not recognizing that because the four propositions are related to the general glut debate, they are intrinsically related to the question of unemployment. Instead, Hollander argues, "The fourth proposition presumed full use of existing capacity. Mill conceded that in the event of available capacity a net expansion of demand for a commodity may stimulate an increase in employment and output in that sector which is not at the expense of activity elsewhere" (Hollander 1985, p. 376).

But the very quote from Mill used by Hollander to support this statement demonstrates that in the circumstances described, no additional capital would be required. Or, if additional capital were required, it could be supplied by the workers themselves, given, first, that they already have an income source and, second, how paltry might be the additional capital requirements. This is the quote from Mill cited by Hollander:

Work which can be done in the spare hours of persons subsisted from some other source, can (as before remarked) be undertaken without withdrawing capital from other occupations, beyond the amount (often very small) required to cover the expense 
of tools and materials, and even this will often be provided by savings made expressly for the purpose. (Mill, quoted in Hollander 1985, p. 376)

The real question, though, is that if Mill had assumed that labor is fully employed, why should he have said anything at all, never mind having taken up so many pages in trying to get his point across? Clearly, Mill would not have taken as much trouble as he did to explain the role of capital in creating employment if full employment was anyways always assured. The very point of the fourth proposition may be negative in stating what could not increase the level of employment, but if he had "presumed full use of existing capacity" and especially full employment of labor, there would have been little point in discussing this fourth proposition at all. But, in light of the general glut controversy, where Malthus had argued that increasing the demand for commodities would increase the demand for labor during recession, Mill's fourth proposition should be seen as a statement about what would not reduce unemployment during periods when unemployment is high.

\section{KEYNESIAN REVOLUTION}

With the change in focus from the supply side to the demand side following the Marginal Revolution, the pathway was opened for the similar shift to a demand-side analysis in the theory of the business cycle. Whether the Keynesian Revolution was in any sense a result of the shift to the demand side at the microeconomic level, the acceptance of aggregate demand as the driving force in macroeconomics made Mill's conception even more remote from the theoretical framework of economists. Say's Law is central to the supply-side conception embedded in classical thought. Its two most noted classical statements were that there is no such thing as a general glut, and demand is constituted by supply. These are at odds with the conception of an economic framework based around incremental demand-side shifts in marginal utility.

By the time Keynes came to write and publish his General Theory in the 1930s, to the extent that Say's Law was an obstacle of any kind, it was a very weak reed indeed. It is no wonder the belief that employment was always positively correlated with aggregate demand for consumer goods was, in the view of Keynes, an "axiom which only halfwits could question" (Hayek 1995, p. 249). By the time he wrote, a demand-side approach had already been embedded in economic theory for more than half a century.

Yet, so far as Mill was concerned, as his fourth proposition tried to make clear, the belief that there can be demand deficiency for all goods and services in aggregate makes it impossible for an economist to understand the actual workings of an economy. Mill made this abundantly clear in the final paragraph of his chapter in which he had outlined "Say's Law": "A theory so essentially self-contradictory cannot intrude itself without carrying confusion into the very heart of the subject, and making it impossible even to conceive with any distinctness many of the more complicated economical workings of society" (Mill 1921, p. 562). We may today reject Mill's conclusion but, in doing so, it is important to have first understood what he had meant. ${ }^{13}$

\footnotetext{
${ }^{13}$ For discussions of modern misinterpretations of Say's Law, see Ahiakpor (2003) and Kates (2003).
} 


\section{CONCLUSION}

Mill himself called the fourth proposition a "paradox." Thompson described it as a "riddle." Alfred Marshall denied its validity. Modern macroeconomic theory, to the extent it is based on aggregate demand, has the built-in presupposition that it is false. And, while there have been some who have tried to give Mill the benefit of the doubt, attempting to see sense by bending Mill's words this way and that, no one has had a seriously good word to say about it without some kind of qualification since 1876, when Leslie Stephen had described it as "the best test of a sound economist."

Yet, whether you agree with Mill or not, his meaning should be clear. He was summing up the conclusions reached by virtually all economists at the end of the general glut debate. Malthus had argued that the recessions of his own time had been the result of a deficiency of demand, which had been caused by too much saving. His solution was an increase in unproductive spending by the landed classes, proposing an increase in aggregate demand, as we would put it today. In attempting to explain why this solution would not work, Mill tried to explain why an increase in the demand for commodities would not be translated into an increase in the demand for labor. This is a conclusion that was never challenged in his own lifetime. Yet, only fourteen years after Stephen made his statement, Marshall could not follow Mill's chain of logic, and so it has continued down to this very day. This paper has, however, explained Mill's point within the context required to understand what he had meant.

Mill's fourth proposition is no paradox. It is not a riddle. It is an answer to those who believe that an increase in unproductive spending can increase the number of persons employed. Mill denied it is possible and was doing no more than expressing the near-unanimous conclusion of the economists of his time at the end of the general glut debate. It was a conclusion embedded within economic theory until the publication of The General Theory in 1936, representing, as it did, the actual meaning of Say's Law within classical economic thought.

\section{REFERENCES}

Ahiakpor, James. 2003. "Say's Law: Keynes Success with its Misrepresentation.” In Steven Kates, ed., Two Hundred Years of Say's Law: Essays on Economic Theory's Most Controversial Principle. Cheltenham: Edward Elgar, pp. 107-132.

Becker, Gary, and William J. Baumol. 1952. "The Classical Economic Theory: the Outcome of the Discussion.” Economica 19: 355-376.

Hayek, Friedrich A. [1941] 2009. Pure Theory of Capital. Auburn, AL: The Ludwig von Mises Institute.

Hayek, Friedrich A. [1966] 1995. "Personal Recollections of Keynes and the 'Keynesian Revolution."” In Bruce Caldwell, ed., Contra Keynes and Cambridge: Essays, Correspondence. Vol. 9, The Collected Works of F. A. Hayek. Indianapolis: Liberty Fund.

Hollander, Samuel. 1985. The Economics of John Stuart Mill. Vols. I and II. Oxford: Basil Blackwell.

Hollander, Samuel. 1987. Classical Economics. Oxford: Basil Blackwell.

Hollander, Samuel. 2000. John Stuart Mill on Economic Theory and Method. Collected Essays III. New York: Routledge. E-book.

Kates, Steven. 1998. Say's Law and the Keynesian Revolution: How Macroeconomic Theory Lost its Way. Cheltenham: Edward Elgar. 
Kates, Steven. 2003. "Economic Management and the Keynesian Revolution: The Policy Consequences of the Disappearance of Say's Law.” In Steven Kates, ed., Two Hundred Years of Say's Law: Essays on Economic Theory's Most Controversial Principle. Cheltenham: Edward Elgar, pp. 67-81.

Kates, Steven. 2014. Free Market Economics: An Introduction for the General Reader. Second edition. Cheltenham: Edward Elgar.

Keynes, John Maynard. [1936] 1973. The General Theory of Employment, Interest and Money. Vol. VII, The Collected Writings of John Maynard Keynes. Edited by Donald Moggridge. London: The Macmillan Press Ltd.

Malthus, Thomas Robert. 1986. The Works of Thomas Robert Malthus. Edited by E. A. Wrigley and David Souden. Vol 5, Principles of political economy: The second edition (1836) with variant readings from the first edition (1820). Part I. Vol. 6, Principles of political economy: The second edition (1836) with variant readings from the first edition (1820). Part II. London: William Pickering.

Marshall, Alfred. [1920] 1947. Principles of Economics. Eighth edition. London: Macmillan.

Mill, James. [1808] 1966a. “Commerce Defended.” In Donald Winch, ed., James Mill: Selected Economic Writings. Edinburgh: Oliver and Boyd Ltd, pp. 85-159.

Mill, James. [1826] 1966b. "Elements of Political Economy.” In Donald Winch, ed., James Mill: Selected Economic Writings. Third edition. Edinburgh: Oliver and Boyd Ltd, pp. 203-366.

Mill, John Stuart. [1871] 1921. Principles of Political Economy with Some of their Applications to Social Philosophy. Edited with an introduction by Sir W. J. Ashley. Seventh edition. London: Longmans, Green, and Co.

Newcomb, Simon. 1886. Principles of Political Economy. New York: Harper \& Brothers.

Ricardo, David. 1951-1973. The Works and Correspondence of David Ricardo. Edited by P. Sraffa with the collaboration of M. H. Dobb. Eleven volumes. Vol. II, Notes on Malthus's principles of political economy. Vol. VIII, Letters, 1819-June 1821. Cambridge: Cambridge University Press.

Sandilands, Roger J. 1990. "Nicholas Kaldor's Notes on Allyn Young's LSE Lectures 1927-29.” Journal of Economic Studies 17 (3/4): 18-170.

Say, Jean-Baptiste. 1821. A treatise on political economy; or the production, distribution, and consumption of wealth. Translated from the fourth edition of the French by C. R. Prinsep with notes by the translator. Two volumes. London: Longman, Hurst, Rees, Orme, and Brown.

Say, Jean-Baptiste. [1821] 1967. Letters to Mr Malthus on several subjects of political economy and on the cause of the stagnation of commerce to which is added a catechism of political economy or familiar conversations on the manner in which wealth is produced distributed and consumed in society. Translated by John Richter. New York: Augustus M. Kelly.

Sowell, Thomas. 1972. Say's Law: An Historical Analysis. Princeton: Princeton University Press.

Spence, William. 1807. Britain independent of commerce; or, proofs, deduced from an investigation into the true causes of the wealth of nations, that our riches, prosperity, and power, are derived from resources inherent in ourselves, and would not be affected, even though our commerce were annihilated. Second edition. London: W. Savage, Bedford Bury for T. Cadell and W. Davies.

Stephen, Leslie. 1876. History of English Thought in the Eighteenth Century. Two volumes. London: Smith, Elder \& Co.

Taylor, Fred Manville. 1909. "Methods of Teaching Elementary Economics at the University of Michigan." Journal of Political Economy 17: 688-701.

Taylor, Fred Manville.1925. Principles of Economics. Ninth edition. New York: The Ronald Press Company.

Thompson, James H. 1975. "Mill's Fourth Fundamental Proposition: A Paradox Revisited.” History of Political Economy 7 (2): 174-192.

Thweatt, William O. 1979. "Early Formulations of Say's Law." Quarterly Review of Economics and Business 19: 79-96.

Wikipedia. 2011. "Fermat's Last Theorem.” http://en.wikipedia.org/wiki/Fermat's_Last_Theorem. Accessed November 2014. 